\title{
Dakwah di Era Disrupsi (Studi terhadap Rekayasa Global)
}

\author{
Usman, Abdul Rani \\ Universitas Islam Negeri Ar-Raniry Banda Aceh \\ Email: arani.usman@ar-raniry.ac.id
}

\begin{abstract}
Da'wah is a solicitation for good, commanding to the makrufand preventing the rebellion. Da'wah for Dinul Islam is a must for Muslims. Da'wah issued by the Prophet Muhammad SAW was continued by Ulul Albab and the preachers to be conveyed to mankind. Da'wah requires strategies and challenges following the phenomena of the times. At present the da'wah in the era of globalization has disruption related to the global geopolitics-economy that occurs, relating to global issues both human rights and politics. This study uses Berlo communication theory. This theory explains the source and receiver of messages about communication skills, attitudes, knowledge, social systems, and culture. This research uses library methods and content analysis. This research shows the da'wah developed by the preachers is plagued by issues of ISIS, radicalism, economic change, and global culture.
\end{abstract}

\section{KEYWORDS: Da'wah, Disruption, Human Rights, ISIS, Radicalism}

\section{ABSTRAK}

Dakwah merupakan ajakan untuk kebaikan, menyuruh kepada makruf dan mencegah kepada mungkar. Dakwah kepada Dinul Islam merupakan kewajiban bagi kaum muslimin. Dakwah yang telah diajarkan oleh Nabi Muhammad SAW diteruskan oleh Ulul Albab dan para da'i guna disampaikan kepada umat manusia. Dakwah yang diajarkan mempunyai strategi dan tantangan sesuai dengan fenomena zaman. Saat ini dakwah di era globalisasi mempunyai disrupsi terutama berkaitan dengan geopolitik-ekonomi global yang terjadi, berhubungan dengan isu-isu global baik Hak Asasi Manusia maupun politik. Penelitian ini menggunakan teori komunikasi Berlo. Teori ini menjelaskan sumber dan penerima pesan dipengaruhi oleh keterampilan komunikasi, sikap, pengetahuan, sistem sosial dan budaya. Penelitian ini menggunakan metode perpustakaan dan analisis isi. Penelitian ini menunjukkan dakwah yang dikembangkan oleh para da'i mempunyai gangguan, pengaruh isu, ISIS, Radikalisme, perubahan ekonomi dan budaya global. 


\section{Pendahuluan}

Dakwah sebagai anjuran untuk merubah sikap dan perilaku manusia guna menyembah Allah dan mengikuti ajarannya yang yang diwahyukan kepada Nabi Muhammad dan diteruskan kepada manusia lainnya sampai akhir zaman. Dakwah yang dikembangkan oleh para da'i sesuai dengan kondisi, fenomena budaya dan zaman. Berkaitan dengan dakwah di era globalisasi telah ditulis oleh Istina Rakhmawati di Jurnal Addin, Vol 8 No 2, 2014, Institut Agama Islam Negeri Kudus. Terkait dengan dakwah di era globalisasi juga telah dipublikasikan oleh Misbahuddin, tentang aktualisasi dakwah di Era Globalisasi (dalam menegakkan Syariat Islam) yang dipublikasikan dalam Jurnal Dakwah Tabligh, Vol,17, No 1, 2016. Namun artikel ini mengkaji tetang disrupsi dan rekayasa global.

Dakwah merupakan seruan untuk mengamalkan Aqidah dan Syariah. Dakwah telah dilaksanakan oleh para Nabi dan Ulul Albab semenjak turunya AI-Qurqan. Namun dakwah dikaji, ditelaah, diteliti dan dan dikaji mulai didirikan Fakultas Dakwah dan Publisistik di Aceh pada 3 Oktober 1968. Setelah pendirian Fakultas Dakwah dan Komunikasi ini terus dikembangkan ilmu dakwah diseluruh Indonesia dan bahkan dunia. Kajian ini masih sangat sedikit dibahas oleh ilmuan dakwah. Inilah letak signifikansinya kajian dakwah di era disrupsi. Adapun argumen dalam artikel ini bagaimana disrupsi dakwah di era globalisasi. Kajian ini membahas dakwah dan disrupsi di era globalisasi terutama yang berkaitan dengan isu-isu global yaitu Hak Asasi Manusia Radikalisme, ISIS dan perubahan sosial yang berkaitan dengan perseteruan Ekonomi, politik Tiongkok dengan Jalur Sutra Maritim yang disebut dengan One Belt One Road.

\section{Pembahasan}

\section{Fenomena Globalisasi}

Pertarungan budaya dan politik telah terjadi ribuan tahun. Peradaban besar seperti Rumawi, Persia dan Cina memainkan peran dalam percaturan politik waktu itu. Pertarungan peradaban yang dibingkai dengan politik dan agama disebutkan dalam Al-Quran Surat Ar-Rum sebagai berikut: Alif Lam Mim. Telah dikalahkan Rum di negeri yang terdekat dan mereka sesudah kekalahan mereka (itu) akan menang dalam sekian tahun (lagi). Milik Allah urusan sebelum dan 
sesudah (itu), dan ketika itu akan bergembira orang-orang mukmin karena pertolongan Allah. Dia yang memenangkan siapa yang dikehendaki-Nya dan Dialah Yang Maha Perkasa lagi Maha Penyanyang. Janji Allah, Allah tidak akan menyalahi janji-Nya, tetapi kebanyakan manusia tidak mengetahui. Mereka mengetahui yang lahir dari sebagian kehidupan dunia; sedang mereka tentang akhirat, adalah mereka orang-orang yang lalai (Ar-Rum, 1-7).

Persia merupakan bangsa besar yang menguasai peradaban dunia pada abad ke 7 Masehi. Rumawi sebagai peradaban yang besar sekaligus mempunyai kekuatan militer yang kuat pada waktu itu. Perebutan kekuasaan dan politik antara Persia dan Rumawi dijelaskan dalam Surat Ar-Rum sekaligus menjadi fokus perhatian kaum muslimin. Terkait dengan kekuatan politik dan ekonomi antara Rumawi dan Persia sangat menonjol dalam sejarah perjalanan dakwah. Fenomena tersebut terjadi pada awal kelahiran Islam. Namun Islam muncul waktu peradaban besar itu berbenturan dan perebutan kekuasaan dan politik. Perebutan pengaruh, politik, ekonomi, wilayah dan kekuasaan menjadi fenomena dakwah pada awal dari kelahiran Islam. Karena Islam akan muncul setelah benturan perdaban tersebut. Peradaban Islam berkembang berkat kaum muslimin mengembangkan dakwah dari Mekkah, Madinah, Persia sampai Andalusia, Asia Tenggara dan Tiongkok. Islam itu muncul berkat para pendakwah mengislamkan budaya Persia dan selanjutkan para da'i mengembangkan dakwah ke seluruh pelosok dunia.

Persia dan Rumawi adalah sebuah kekuasaan besar yang dihadapi oleh umat Islam pada awal Masehi. Kekuatan politik dihadapi oleh para da'i untuk mengembangkan dakwah ke seluruh pelosok dunia. Dakwah yang akan dijalanlan berhadapan dengan kekuatan besar dunia. Namun para da'i dapat memahami fenomena sosial dengan pendekatan budaya yaitu memahami bahasa, tradisi dari sasaran dakwah. Dan terbukti para da'i dapat mengislamkan peradaban Persia. Peradaban Persia selain menyimpan berbagai khazanah teknologi dan ilmu pengetahuan sekaligus, Persia menjadi salah satu kekuatan Islam sampai saat ini. Peradaban Rumawi juga pernah dikuasai oleh kaum muslimin dengan pendekatan budaya. Para pendakwah menguasai bahasa dan budaya sehingga dengan mudah dapat mengembangkan dakwah dengan 
suasana damai dan tenteram.

Sehubungan dengan kekuasan Persia dan Rum disebutkan dalam Shihab sebagai berikut: Kekalahan satu kerajaan, apalagi yang adidaya atas adidaya yang lain, merupakan satu hal yang luar biasa. Lebih-lebih bila disusul dengan kemenangan setelah kekalahannya dalam beberapa tahun saja. Untuk itu, setelah pernyataan di atas, makna diawal surat Ar-Rum ini menggarisbawahi mengapa semua itu terjadi dengan menyatakan bahwa: Milik Allah semua urusan sebelum kemenagan Persia dan sesudah kemenangan dan kekalahan itu. Dan ketika yakni pada masa kemenangan Byzantium itu akan bergembira orangorang mukmin karena pertolongan Allah, atau kemenangan yang mereka raih dan yang bersumber dari Allah. Dia yang menyenangkan dan menolong siapa yang dikehendaki-Nya sesuai dengan hikmah kebijaksanaan-Nya dan Dia pula yang menjatuhkan kekalahan atas siapa yang dikendaki-Nya sesuai sunnatullah yang ditetapkan-Nya (Shihab, 2007)

Memahami fenomena yang dikisahkan dalam Surat Rum menjadi pedoman bagi para da'i dalam mengembangkan dakwah. Fenomena lahir dan tengelamnya suatu budaya atau kekalahan dan kemenangan suatu kekuatan dunia merupakan kehendak Allah. Yang menentukan kemenangan dan kekalahan merupakan kehendak Allah. Kewajiban para da'i adalah mengembangkan dan menyiarkan agama Allah ke seluruh pelosok dunia. Kebangkitan dan kemunduran suatu peradaban dapat diramalkan namun kepastian itu ada pada kehendak Allah. Allah yang menentukan segalanya di dunia ini. Kewajiban da'i untuk menyiarkan dakwah tidak memandang budaya dan peradaban tersebut akan mundur atau lahir, akan tetapi kemampuan da'i dalam menjalankan strategi dakwah itulah yang sangat dipentingkan oleh para pendakwah dalam segala tantangan dunia dulu, kini dan sampai akan datang. Tantangan dakwah silih berganti mengikuti perkembangan zaman. Para da'l melanjalankan dapat menyiasati berbagai strategi dakwah guna Islam itu berkembang sampai akhir zaman.

Kekuatan Timur dan Barat yaitu Persia dan Rumawi adalah sebuah fenomena sejarah yang dinukilkan dalam Surat Ar-Rum ayat 1 sampai 7. Namun demikian setiap kekuatan dan kekuasaan menjadi kolonialisasi akan musnah dengan 
sendirinya karena mereka korup, congkak dan sombong serta menindas. Kaum muslimin terutama da'i menyakinkan umat Islam akan ada harapan untuk memenangkan dan menguasasi peradaban dengan membela kaum yang tertindas dan lemah. Fakta tersebut telah dibuktikan oleh kaum muslimin pada awal datangnya Islam. Penganut Islam yang pertama adalah orang-orang yang lemah dalam bidang ekonomi dan politik. Akan tetapi kaya hati dan spiritual. Jika pun mereka kaya dan terhormat, namun ia tetap mendapat hinaan dari kaum musyrikin. Ketabahan para ulul Albab dan da'i tempo dulu menyebakan Islam berkembang sampai akhir zaman. Sumber ketabahan dan kesabaran da'l merujuk kepada Al-Quran dan Hadis Nabi.

Sehubungan penguasanya dunia dalam Syari'ati dijelaskan: Biarkan saja mereka menyatakan keabadiannya, sebagai penguasa manusia dan pemilik dunia! Mereka lupa pada ketentuan sejarah di mana setiap kekuasaan akan hancur dan musnah pada akhirnya. Sedangkan tentang keadaan masa kini, meskipun Kekaisaran Barat dan Timur telah membagi dunia di antara mereka sendiri, situasi ini tidak akan berjalan lama. Mereka pasti akan tumbang dan jatuh; dengan demikian, kaum, kaum Muslimin harus diyakinkan dan mengharapkan datangnya kemenangan di masa mendatang (Syari'ati, 1988). Para da'i selain terdidik dan alim sekaligus mempunyai visi dan misi serta melihat masa akan datang lebih bagus daripada saat ini. Adanya keinginan da'i untuk melihat masa datang lebih bagus menyebabkan para da'i dapat hidup berdampingan serta dapat menyesuaikan dengan zaman yang serba berubah.

Kemegahan dan kemunculan suatu peradaban tidak akan abadi. Namun semua kejadian dan fenomena kekuatan dunia baik di Barat maupun di Timur adalah suatu kehendak Allah. Bangsa apapun yang mampu mempersiapkan kekuatan ilmu pengetahuan, politik, ekonomi dan militernya, mereka akan menguasai dunia. Namun kehancuran itu tidak dapat ditentukan dengan serta merta namun semua tindakan manusia dikendali oleh Allah. Umat Islam harus diyakinkan oleh para da'i guna membangun suatu peradaban yang kuat sehingga Islam menguasai dunia. Dunia dapat dikuasai apabila suatu umat mampu berkarya dan bekerja keras seraya mempersiapkan sumber daya manusia yang terampil dan cerdas. Fenomena tersebut telah dilakukan oleh umat Islam 
tempo dulu yang telah menguasai kekuatan dunia baik Persia maupun Rumawi.

Setelah perang dingin antara Uni Soviet dengan Amerika selesai, kekuatan dunia terkesan hanya satu yaitu Amerika. Namun Tiongkok sebagai salah satu peradaban tua dunia sebagai penyeimbang mempunyai mimpi untuk menguasai dunia dengan damai melalui budaya. Saat ini Tiongkok sebagai salah satu kekuatan ekonomi dan budaya yang sangat diperhitungkan dunia. Dalam khazanah Islam Tiongkok merupakan suatu kekuatan ilmu pengetahuan yang harus dipelajari oleh umat Islam. Fenomena akan datang adalah lahirnya kekuatan politik dan ekonomi baru yaitu Tiongkok. Inilah salah satu disrupsi dakwah di era global ini. Persiapan untuk menghadapi tantangan politik dan ekonomi Tiongkok maka para pendakwah dan umat Islam mengupayakan memahami, fenomena kebangkitan peradaban Konghucu melalui mimpi mereka dengan pendekatan budaya dan menciptakan keseimbangan antar kekuatan di dunia global. Secara membuktikan bahwa umat Islam dianjurkan untuk mencari Ilmu sampai ke negeri Cina. Fakta sejarah tersebut menunjukkan bahwa umat Islam berupaya berkoloborasi dengan budaya Tiongkok seraya mempersiapkan diri membina hubungan harmonis guna Islam berjaya lagi di Tiongkok. Peradaban Tiongkok bersentuhan dengan Islam maka benturan peradaban Islam dengan Tiongkok dapat dihindari dengan prakarsa para da'i di masa akan datang.

\section{Peluang Dakwah Antar Peradaban}

Sejarah peradaban menunjukkan Persia dan Rumawi sebagai kekuatan besar. Negara adikuasa tersebut telah menguasai dunia, juga mereka menguasai ilmu pengetahuan, teknologi dan militer. Setelah adikuasa menguasai ilmu pengetahuan dan teknologi maka mereka menjadi sebuah kerajaan yang besar pengaruhnya, sehingga menjadi kolonialisasi ke berbagai negara yang belum maju. Kolonialisasi dan ekspansi menjadi keharusan bagi mereka untuk menguasai dunia. Peradaban Persia sudah berkembang ratusan tahun sebelum Masehi. Berkembangnya budaya Persia erat kaitannya dengan motivasi dan tantangan yang dihadapi oleh bangsa tersebut diantaranya alamnya yang sangat gersang dan tidak bersahabat, letak geografi antar benua-teluk dan budaya klasik di Persia. Kemasyhuran Islam tempo dulu adalah dapat mengislamkan budaya Persia sekaligus mewarnai Persia dengan berbagai kesucian Islam. Islam di Persia 
tidak dapat dipengaruhi oleh kapitalisme dan sosialisme. Namun Islam di Persia mengandalkan konsep Islam yang sesuai dengan perkembangan ilmu pengetahuan dan teknologi saat itu.

Setelah Islam datang ke Persia melalui dakwah dan para da'i mensyiarkan keharmonisan dan membawa aqidah Islamiyah seraya membela kaum tertindas, maka Islam tampil ke permukaan dan menjadi raksasa selama tujuh abad. Islam berkembang berkat kerja keras para da'i dalam kondisi zaman dan tantangan yang berbeda-beda. Walau bagaimanapun Islam terus maju memahami peradaban dan Islam mengikuti suasana budaya dan peradaban setempat sehingga Islam menjadi landasan hidup bagi kaum muslimin. Pengembangan Islam dengan motivasi da'i dan mengikuti petunjuk Rasulullah. Fenomena tersebut sebagaimana dipesankan oleh Rasulullah, bahwa Islam akan menguasai peradaban dunia dengan semangat suci memberdayakan dan memperhatikan kaum dhuafa.

Setiap zaman mempunyai kekuatan besar baik di Timur maupun di Barat. Kekuatan dan kekuasaan mempunyai pengaruh yang signifikan dalam perubahan dan pembentukan peradaban dunia. Setelah Islam berkembang mewarnai peradaban dunia sehingga mempunyai pengaruh kekuatan ekonomi dan politik. Persentuhan dan benturan peradaban Timur dan Barat menjadikan Islam sebagai penyeimbang dan penyambung peradaban harmonis antara Barat dan Timur serta Islam bermitra politik dan dagang dengan Tiongkok. Karena Islam juga berpengaruh di Tiongkok yang dikembangkan oleh para da'i dengan konsep adaptasi dan akulturasi budaya terutama melalui perdagangan dan politik. Demikian juga Tiongkok sebagai salah satu peradaban tertua juga mempunyai pengaruh terutama dalam mengembangkan konsep politik dan ekonomi melalui jalur sutra kuno. Demikian juga saat ini peradaban dan kekuasaan besar ada di Amerika dan di Tiongkok. Artinya perebutan kekuasaan dan benturan politik masih terjadi dan keruntuhan serta kemunculan peradaban baru tidak dapat diramalkan oleh manusia namun semua karena kehendak Allah semata. Akan tetapi para da'i mengingatkan bahwa Islam menjadi ideologi dan politik guna menjadi pengaruh setiap pelosok dunia. 
sekaligus harapan bagi umat Islam. Tantangannya adalah umat Islam mengharapakan mengikuti irama poltik dan ekonomi Tiongkok dengan Jalur Sutra martiim mereka. Jalur sutra maritime mereka adalah membuat konektivitas Eurasi, eropa dan Afrika. Umat Islam khususnya da'i selain bermitra sekaligus dapat belajar banyak dari kebangkitan politik dan ekonomi China. Sedangkan harapannya adalah Tiongkok mempunyai sejarah diplomasi harmonis dengan Islam terutama pada masa Khalifaurrasyidan, dan Bani Umayyah serta Bani Abbasyiah. Keharmonisan tersebut merupakan cikal bakal diplomasi harmonis dalam bidang politik dan ekonomi dengan umat Islam masa akan datang. Umat Islam jika mampu berakulturasi dengan Konghucu maka kemakmuran akan diraih di masa akan datang. Saling membantu dan pengertian antara Islam dan Tiongkok dibuktikan dengan kedatangan diplomat Islam Saad bin Abi Waqas ke Quanzho pada abad pertama Hijriah dan Pemerintah Tiongkok menerima dengan senang hati dan Saad pun mendirikan Masjid di Quanzhou sebagai simbol keharmonisan antara Tiongkok dan Umat Islam.

\section{Dakwah di Era Disrupsi}

Dakwah dikembangkan setiap saat di mana saja dan kapan saja, tidak mengenal ruang dan waktu. Artinya dakwah dilakukan oleh setiap muslim sesuai kapasitas dan kemampuannya. Dakwah saat ini sedikitnya mengalami ganguan dan tantangan, terutama berkaitan dengan Hak Asasi Manusia (HAM). Setiap Negara mengalami dan mempunyai kasus HAM. Berbicara mengenai kasus HAM di Indonesia sangat banyak sehingga sangat sulit untuk dituntaskan. Menurut Jaksa Agung St Burhanuddin sebanyak 15 kasus pelanggran HAM berat yang ditangani oleh J aksa Agung. Tiga kasus telah di selesaikan. Dan 12 perkara belum selesai. Dari 12 perkara, sebanyak 8 kasus terjadi sebelum terbitnya Undangundang nomor 26 tahun 2000 tentang Pengadilan HAM. Ke delapan tersebut adalah peristiwa 1965, peristiwa Penembakan Misterius (petrus), Peristiwa Trisakti, Semangi I dan Semangi II tahun 1998, peristiwa Penculikan dan Penghilangan Orang Secara Paksa, Peristiwa Talangsari, peristiwa Simpang KKA, Peristiwa Rumah Geudong tahun 1989, Peristiwa dukun santet, ninja dan orang gila di Banyuwangi tahun 1998 (Erdianto, 2019). 
pengalaman yang menyedihkan karena terjadi pelanggaran HAM. Para pengamat asing cenderung mempersalahkan pemerintah, sebagai pelaku pelanggaran HAM. Gangguan tersebut merupakan salah satu disrupsi bagi para da'i jika berhadapan dengan isu global lainnya yang dibawakan dengan informasi yang tersiar dengan cepat. Sebagai warga negara dan umat Islam merasa terganggu dengan adanya kejadian tersebut sehingga menjadi gangguan dan kendala dalam mengembangkan dakwah apabila berhadapan dengan orang yang berbeda agama dan berbeda paham terutama orang yang membawa isu globalisasi dan demokrasi. Demikian juga isu-isu kerusuhan Papua baru-baru ini.

Kasus kerusuhan di Wamena, Papua masih terdapat berita bohong yang beredar pasca kerusuhan. Kegiatan ekonomi sudah mulai jalan, namun masih ada berita-berita hoaks atau berita-berita yang memengaruhi psikologi massa, kata Kapolda, Papua Irjen Paulus Waterpau (Halim, 2019). Paulus mengimbau untuk berhenti memberikan pemberitaan yang membohongi rakyat, yang mengintimidasi rakyat, apalagi kekerasan. Kerusuhan Wamena terjadi tanggal 23 September 2019. Kerusuhan tersebut dilatarbelakangi dugaan tindakan rasial mengakibatkan pembunuhan, penganiyaan, kemudian terjadi pembakaran sejumlah kantor pemerintah, fasilitas umum dan pemukiman masyarakat. Kerusuhan Wamena Papua merupakan disrupsi yang dilakukan oleh segelintir masyarakat, sehingga membuat masyarakat kacau, tidak nyaman dan terjadi kerusuhan. Fenomena tersebut merupakan disrupsi yang menggangu kenyamanan dari masyarakat.

Jika dianalisis maka disrupsi yang terjadi di Papua merupakan berita kebohongan yang mengganggu ketenteraman masyarakat. Disrupsi tersebut memang terkait dengan politik. Akan tetapi sangat mengganggu aktivitas pemerintah dan masyarakat sekaligus berpengaruh terhadap kehidupan umat beragama. Jika kerusuhan tersebut dikaitkan dengan politik-agama maka kebanyakan orang yang datang dari luar umumnya beragama Islam dan kebanyakan masyarakat Papua adalah non-muslim. Fenomena tersebut tidak semuanya benar, namun berita hoaks yang menyesatkan tersebut membuat keresahan masyarakat Indonesia lainnya yang beragam agama. Dilihat dari segi 
dakwah maka terjadi disrupsi atau ganguan yang dilakukan oleh sekelompok orang membuat kekacauan sehingga kehidupan bermasyarakt terganngu dan akhirnya terusik pula kehidupan beragama. Disrupsi di sini juga berpengaruh terhadap kegiatan keagaman terutama kegiatan dakwah di Papua. Fenomena tersebut berpengaruh terhadap kegiatan dakwah.

Berkaitan dengan isu HAM juga terjadi di Tiongkok. Saat ini, lebih dari 1 juta warga Uighur, etnis Kazakh dan warga Muslim lainnya ditahan dalam kamp-kamp pendidikan ulang yang didesain untuk menghilangkan identitas keagamaan dan etnis mereka, "ucap Pompeo, saat membahas laporan tahunan. Dalam forum di Jenewa ini Kelly Currie dan pembicara lainnya, termasuk para pakar dan seorang mantan tahanan di Xinjiang, melontar tuduhan serupa. Namun menurut diplomat Tiongkok menolak tudahan tersebut. Tiongkok memerangi ekstremisme dan sepratis melalui pendidikan kejuruan (Zahid, 2019).

Isu HAM terjadi di mana-mana baik di Indonesia maupun di tempat lainnya seperti di Tiongkok. Pelanggraran HAM seperti yang dituduhkan terhadap pemerintah Tiongkok di Xinjiang merupakan tantangan bagi para pendakwah dalam mengembangkan dakwah mereka. Hal ini menunjukkan bahwa para da'i di Tiongkok selain sangat hati-hati dalam mengembangkan dakwah sekaligus sangat sensitif. Karena mereka merupakan warga minoritas yang hidup berdampingan dengan etnis lainnya. Demikian juga Muslim di China merupakan warga Negara yang sudah hidup rukun dan damai ribuan tahun yang lalu. Dengan adanya isu pelanggaran untuk memerangi ekstremisme menjadi persoalan dan tantangan da'i dalam mencermati dakwah sesuai dengan budaya dan sistem politik komunis. Harapan da'i banyak strategi dakwah yang dilakukan oleh para da'i di negara yang dilanda isu HAM. Kelihaian dan kecerdasan emosional da'i sangat diperlukan dalam memaknai fenomena dan tantangan dakwah di negara yang dilanda isu HAM.

Di samping isu radikalisme di Indonesia sangat menggangu jalannya kegiatan dakwah. Radikalisme merupakan paham yang menginginkan perubahan dengan kekerasan. Radikalisme tidak identik dengan suatu agama. Akan tetapi radikalisme merupakan sekelompok orang yang ingin memanfaatkan kesempatan guna meraih kekuatan politik. Radikalisme di Indonesia sudah mulai 
berkembang. Sebagian masyarakat mengaitkan radikalisme dengan agama tertentu. Radikalisme ada di mana-mana di seluruh dunia. Wakil Menteri Agama, Zainut Tauhid mendukung upaya pemerintah dalam memberantas radikalisme di Indonesia. Hakikatnya seluruh masyarakat sepakat menolak radikalisme. Menurut Zainut Tauhid radikalisme ini bisa hadir di tengah-tengah kita dalam keadaan apapun. Apakah dia berselimut agama, apakah dalam bentuk-bentuk yang lain, kita semua harus bersama-sama untuk menolak paham radikal (Amalia, 2019).

Indonesia sebagai Negara yang mayoritas memeluk agama Islam sangat menolak isu radikalisme dikaitkan dengan agama tertentu. Ketegasan pemerintah untuk menolak radikalisme sangat didukung oleh masyarakat. Terkait dengan gangguan terhadap pengembangan dakwah di Indonesia sangat signifikan, karena radikalisme dibalut dengan bingkai agama. Para pendakwah selain menolak radikalisme sekaligus sangat menggangu para da'i dalam melakukan kegiatan dakwah terutama di daerah yang sangat plural. Konsekuensi logis dari penolakan terhadap isu radikalisme, para da'i melarang umat umat Islam untuk mengikuti ajakan terhadap radikalisme. Para da'i dianjurkan menangkal isu radikalisme tersebut.

Para da'i yang berdakwah baik kepada intern umat atau komunikasi antar umat memberi petunjuk agama berdasarkan Al-Quran dan Hadis guna tidak menyimpang seperti terjebak kepada isu-isu radikalisme dan paham-paham lain yang menggangu keberlangsungan dakwah dalam masyarakat. Karena dakwah menganjurkan kepada jalan Allah seraya mengamalkan aqidah dan syariat untuk kemaslahatan manusia dunia dan akhirat. Para da'i juga memahami Islam yang rahmatal lilalamin. Artinya dakwah yang dikembangkan adalah sesuai dengan petunjuk Al-Quran dan Hadis. Seorang da'i menjadikan figur dan model dakwah adalah dari Rasulullah SAW. Jika seorang da'i dapat menerapkan model sebagaimana petunjuk para Nabi maka dakwah akan berhasil. Dan gangguanpun tidak terjadi, serta dakwah dapat diterima di mana saja dan kapan saja.

Terkait gangguan disrupsi dakwah di era ini adalah timbulnya ISIS (Islamic State in Iraq and Syira). Sehubungan dengan ISIS Guardian melaporkan bahwa sebagian besar gembong ISIS adalah orang-orang yang dulu pernah berada di bawah pengawasan tentera dan intelejen Amerika Serikat (AS) di Irak. 
Pemerintah AS membuat penjara Kamp Bucca. Di dalam penjara itulah sebagian besar gembong jaringan teroris Al-Qaeda dan cikal bakal pemimpin ISIS ditampung sehingga Kamp Bucca menjadi titik awal proses pergerakan spektakuler kelompok-kelompok ekstrimis (Ravishop, 2014). ISIS pada awalnya adalah orang-orang yang ditahan di Kamp Bucca. Penjara inilah yang membentuk para ektremis untuk membentuk pemikiran yang ekstrem terhadap pemikiran dan membentuk ideologi kekerasan.

Pengaruh ISIS di Indonesia telah dirasakan dengan adanya sekelompok orang yang menyebar kebencian terhadap negara dan kemapanan saat ini, karena latarbelakang lahirnya ISIS ini menunjukkan bahwa ekstremis juga merambah negara yang mayoritas masyarakat Islam. Terkait dengan ISIS disebutkan dalam Nainggolan: Mobilitas yang tinggi, yang didukung perkembangan teknologi alat transportasi dan komunikasi yang sangat modern, telah memungkinkan para pelaku aksi terorisme, pendukung, dan simpatisannya ke wilayah manapun bergerak. Wilayah dengan latarbelakang kemiskinan dan ketidakadilan sosial yang tinggi, jauh lebih rawan sebagai pilihan para teroris untuk menjadikannya sebagai safe haven, basis perekrutan, organisasi dan kegiatannya (Nainggolan, 2017).

Lahirnya ISIS ditandai dengan keterbelakangan pendidikan dan sempitnya pemahaman terhadap agama. Ditambah dengan letak geografis yang terpencil sekaligus kemiskinan yang melanda anggota ISIS. Jika dikaji lahirnya ISIS di Irak adalah selain mereka tertindas sekaligus aktivitas mereka terkendali dengan konsentrasi Kamp Bucca yang dimiliki oleh Amerika di Irak. Analisis menunjukkan bahwa kelahiran dan keberadaan ISIS adalah setelah runtuhnya rezim Saddam Husen. Irak sebelumnya adalah negara yang stabil di Timur Tengah, namun diekspansi oleh Amerika 20 Maret 2003 sehingga runtuhlah Republik Irak yang dikomandoi oleh Saddam Husen. Setelah ISIS berkembang di Irak dan Suriah, akhirnya menjalar ke negara lainnya.

Terkait dengan dakwah yang dikembangkan oleh para da'i terutama di Indonesia maka terganggu oleh adanya isu ISIS. Isu ekstremis menjadi ancaman dari kemapanan yang sedang terjadi. Terkait dengan aktivitas dakwah, para da'i mempersiapkan dirinya dan mad'unya tidak termakan isu ISIS yang ada di Irak. 
Namun para da'i mewaspadai kegiatan ekstremis di dalam masyarakat Islam. Sehubungan dengan kegiatan dakwah secara intern umat Islam, para da'i memberi penjelasan terhadap keberadaan ISIS yang sebenarnya bukanlah Islam. Sedangkan kewajiban da'i untuk memberikan penerangan kepada temantemannya yang berbeda agama maka menyebutkan ISIS adalah kegiatan anti kemapanan yang dilatarbelakangi oleh kemiskinan dan keterbelakangan. Dan ekstremisme juga berlaku di mana saja dan kapan saja dan tidak ada kaitannya dengan agama manapun.

Di samping itu terjadinya kecemasan para da'i yaitu isu kebangkitan politik ekonomi dan politik Tiongkok. China sebagai bangsa dan peradaban besar dunia memainkan peran dalam percaturan politik dan ekonomi pada masa yang akan datang. Setelah kebangkitan ekonomi yang digerakkan oleh Deng Xiaoping tahun 1978, China bangkit dan membangun ekonomi liberal, yaitu mementingkan pasar guna kepentingan masyarakat dan bangsanya. Menurut Tianyong, setelah 30 tahun sejak reformasi dan keterbukaan dan pada dekade pertama abad ke 21, Tiongkok berupaya menyesuaikan arah dan mengeksplorasi jalan baru menuju keharmonisan sosial dan pengembangan ilmiah sesuai dengan pola, situasi dan masalah dunia baru di masa depan (Tianyong, 2019)(9, 20).

Pembaruan politik dan ekonomi Tiongkok dimulai dari era Deng Xiouping dan dilanjutkan oleh Xi J inping. Xi merancang konsep satu sabuk satu jalan (One Belt One Road). Konsep satu sabuk dan jalan dirancang oleh Presiden Xi J inping Oktober 2013. Rancangan satu sabuk satu jalan sebagai langkah mimpi China untuk bangkit membangun budaya dan politik mereka yang menghubungkan Asia, Afrika dan Eropa. Konsep One Belt One Road membangun peradaban mereka dengan harmonis melalui budaya dan politik ekonomi. Kemampuan Tiongkok membangun konektivitas infrastruktur, darat, laut, udara melalui konektivitas people to people. Konsep satu sabuk satu jalur menjadi harapan bagi Tiongkok dan Asia lainnya membangun peradaban Asia. Inisiatif jalur sutra dengan merancang infstruktur termasuk di Indonesia kerjasama membangun jalur kereta api cepat Jakarta-Bandung. 
dilakukan penandatangan $23 \mathrm{MOU}$ antara pebisnis Indonesia dan China dalam acara Konferensi Tingkat Tingg (KTT) II Belt Road Initiative (BRI) di Beijing. Proyek Obor menurut Fadli Zon Wakil Ketua MPR RI mengatakan inisiatif BRI dilihat para pengamat Barat sebagai cara untuk mengukuhkan dominasi China dalam jaringan perdagangan global, termasuk berpotensi menjadi alat ekspansi militer mereka. Kita menghormati RRC, namun kita juga mewaspadai segala politik ekspansionis yang merugikan kepentingan nasional (Sebayang, 2019). Perkembangan ekonomi Tiongkok selain menjadi harapan bagi Indonesia membangun konektivitas melalui budaya dan infrastruktur sekaligus kekhawatiran bagi politikus Indonesia sehingga kewaspadaan diantisipasi sedemikian rupa.

Terkait dengan dakwah di era globalisasi dan disrupsi ini para da'i baik di Indonesia maupun di dunia lainnya memaknai kebangkitan Tiongkok sebagai harapan baru bagi perkembangan Islam masa depan. Karena Islam dan Tiongkoh mempunyai pengalaman harmonis tempo dulu terutama pada Dinasti Tang dan Dinasti Ming. Pengalaman keharmonisan antara Islam dan khonghucu menjadi harapan baru komunikasi berdasarkan spiritual. Karena Islam telah mewarnai kebudayaan Tiongkok tempo dulu, sehingga keharmonisan antara Islam dan budaya Tiongkok masih terjaga sedemikian rupa sampai saat ini. Dan hubungan Tiongkok dengan Timur Tengah terjalin harmonis serta tidak dapat dihapus walaupun budaya Barat berkembang di Tiongkok.

Para da'i memaknai kebangkitan ekonomi dan politik Tiongkok sebagai peluang mengembangkan dakwah baik di Negara Tiongkok sendiri maupun dengan etnis China di Indonesia. Pemerintah Tiongkok menghargai nilai-nilai budaya Indonesia yang dibingkai dengan Islam. Dan di Tiongkok sendiri Islam berkembang dan berkiprah lagi. Fenomena inilah peluang dan harapan kebangkitan Islam bergandengan tangan dengan kebangkitan ekonomi dan politik Tiongkok. Para da'i selain memanfaatkan peluang ini sekaligus komunikasi antar da'i Indonesia dan Tiongkok dipererat sedemikian rupa melalui jalur politik dan budaya. Pererat silaturahmi antara diplomat Indonesia dan Tiongkok menjadi roh bagi pengembangan Islam di masa akan datang. Komunikasi harmonis pemimpin Indonesia dan Tiongkok sebagai spirit bagi dai'i dalam 
mengembangkan dakwah pada masa mendatang. Demikian juga para da'i Indonesia setidaknya memahami bahasa Mandarin guna mengembangkan dakwah di Tiongkok. Sebaliknya para Imam di Tiongkok juga diberi peluang untuk mempelajari bahasa Indonesia dan Islam di Indonesia guna membangun Islam yang rahmatal lialamin di masa akan datang.

\section{Analisis dan Diskusi}

Para da'i saat ini membutuhkan keterampilan multi displin, terutama berkaitan dengan budaya global. Era revolusi 4.0 merupakan suatu era yang sangat kompleks terutama berkaitan dengan ekonomi, politik isu HAM, radikalisme dan ISIS. Para da'i mempersiapkan materi yang sesuai dengan kondisi mad'u. Pendakwah masa kini selain menguasai teknologi informasi sekaligus memahami politik regional dan internasional. Setelah perang dingin usai maka Tiongkok semakin berperan terutama dalam bidang ekonomi. Para da'i memahami fenomena tersebut dengan mempersiapkan kader dakwah dalam berbagai bidang. Kader yang dibutuhkan selain menguasai, politik, teknologi fenomena sejarah hubungan Islam-Tiongkok.

Isu HAM yang terjadi baik di Indonesia, di Tiongkok maupun di dunia lainnya memerlukan kajian yang mendalam sehingga kasus HAM tersebut apakah dilakukan atau terjadi kepada umat Islam. Isu yang sering didengungkan oleh negara adikuasa adalah mengenai Hak Asasi Manusia (HAM) Islam dan Negara berkembang. HAM yang didengungkan oleh negara barat sebagai hal yang sangat sensitif bagi umat Islam. Pelanggaran yang dilakukan oleh negara Islam kepada bangsanya sangat menyesakkan hati. Saat ini kita dapat menyaksikan bagaimana Suriah, Lebanon dan Mesir. Dan yang sangat menyedihkan adalah Mesir. Baru setahun Morsi memegang pimpinan, ia dikudeta oleh meliter Mesir. Fenomena tersebut menjadi menarik untuk ditelusuri, kenapa hal itu terjadi di negara yang mayoritas umat Islam. Demikian juga di Indonesia, sejak dulu pelanggaran HAM telah terjadi baik masa Orde Lama, Baru atau sesudahnya. Isuisu tersebut memang dilakukan oleh negera yang mayoritas umat Islam. Akan tetapi orang-orang Barat tidak melihat kenapa hal itu terjadi. Fenomena HAM sebagai fenomena menarik dipahami oleh da'i masa kini guna dapat 
mengembangkan dalam berbagai peluang dan dimensi.

Kajian yang mendalam dilakukan oleh da'i adalah adanya isu ISIS di Indonesia atau di belahan dunia lainnya. Isis menjadi isu sentral di dalam negara yang mayoritas umat Islam. Fenomena tersebut menjadi fokus perhatian para da'i. Karena ISIS tersebut sebenarnya hanyalah sekelompok orang yang tertindas sekaligus anti kemapanan sehingga mereka membenarkan kekerasan untuk mencapai tujuan politik mereka. Isu radikalisme erat kaitannya dengan kemauan segelintir orang untuk mencapai kehendak politik dengan memanfaatkan pemikiran radikal sehingga mempengaruhi orang lain dan mengancam kestabilan negara. Para da'i memaknai radikalisme sebagai gangguan zaman ini, sehingga mereka dapat menolak radikalisme dan mengembangkan dakwah sesuai dengan anjuran suci yaitu dengan ajakan, seruan yang lembut kepada jalan Allah.

Demikian halnya ekonomi Tiongkok saat ini mengungguli Amerika Serikat, sehingga para da'i memandang kebangkitan politik ekonomi Tiongkok sebagai peluang membangun peradaban Islam. Fenomena ekonomi politik Tiongkok dengan semboyan mimpi China adalah mengembangkan kemampuan dan potensi Tiongkok guna membangun relasi budaya berdasarkan keseimbangan dan menghargai nilai-nilai universal. Artinya peluang kebangkitan ekonomi China memaknai relasi Islam-Konghucu sebagai keniscayaan guna mengembangkan dakwah. Fenomena politik dan ekonomi Tiongkok memaknai keunggulan dan kompetitif dalam membangkitkan kemesraan budaya Islam dan Tiongkok.

Pengalaman penulis selama belajar di China dua semester di Nanjing Normal University, melihat gejala, bahwa umat Islam sudah mulai belajar di China baik teknologi maupun bisnis. Sebaliknya, Barat sudah mulai kewalahan menghadapi China baik secara ekonomi maupun politik. Fenomena tersebut membentuk relasi dan diplomasi yang sangat bagus dengan umat Islam. Akan tetapi ada gejala lain yang perlu dicermati oleh umat Islam, terutama para da'i yaitu mengisi kekosongan batin atau ketiadaan iman mereka. Kesempatan tersebut menjadi harapan umat Islam saat ini. Salah satu cara adalah mempelajari budaya dan bahasa Mandarin guna berdakwah di kalangan etnik China baik di negera China 
maupun perantauan.

Di samping itu, tantangan umat Islam saat ini adalah para muallaf yang semakin bertambah setiap waktunya. Namun hingga kini penangganan para muallaf tidak komprehensif. Penyelamatan iman para muallaf dirasa sangat kurang. Buktinya banyak anak peranakan mereka tidak mendapat pendidikan agama secara bagus. Kasus yang terjadi saat ini, anak-anak peranakan menjadi kebingungun mencari identitas mereka. Misalnya seorang etnik China yang sudah masuk Islam, maka semua identitas kecinaan mereka hilang. Identitas bahasa mereka hilang. Identitas agama hilang. Identitas bangsa juga hilang. Akan tetapi ada kasus setelah mereka masuk Islam mereka kadang-kadang ditinggalkan oleh suaminya dan tidak tahu harus pulang ke mana lagi. Pulang ke rumah orang tuanya tidak diterima. Pergi ke komunitasnya tidak diterima, akhirnya ia bingung dan kadang-kadang tidak jarang mereka kembali ke agama nenek moyangnya.

Banyaknya muallaf sebagai konsekuensi logis dari perubahan sikap masyarakat terhadap umat Islam. Para muallaf membutuhkan spiritual yang terus menerus guna memantapkan iman mereka. Da'i memaknai keberadaan muallaf sebagai perubahan sikap suci guna mengesakan Allah. Artinya para muallaf selain membutuhkan jiwa yang damai sekaligus mereka membutuhkan perhatian dan relasi keagamaan yang universal. Makna Islam yang kaffah diterapkan kepada hati suci para muallaf guna mereka nyaman dan tenang dengan semangat keislaman yang damai, nyaman dan harmonis. Keberadaan muallaf baik di Indonesia maupun di Tiongkok menjadi harapan dan tantangan para da'i di masa yang akan datang.

\section{Simpulan}

Dakwah mengajak dan menggerakkan kepada dinul Islam, seraya menyeru kepada kebaikan dan melarang kepada yang mungkar. Sumber dan referensi dakwah adalah Al-Quran dan Hadis. Model dan figur yang harus diteladani oleh para da'i adalah Rasulullah. Menjalankan dakwah sebagai tugas yang suci dan mulia diemban oleh para ulul Albab dan da'i. Dakwah di era revolusi 4.0 mempunyai disrupsi karena media sosial berpengaruh terhadap relasi dan 
interaksi antar manusia dalam masyarakat tidak mengenal ruang dan waktu. Ganguan dakwah yang terjadi zaman ini adalah berperannya media sosial sehingga informasi dengan cepat diterima, namun pesan yang disampaikan belum tentu benar, banyak orang dapat menerimanya tanpa menganalis terlebih dahulu.

Gangguan dakwah yang dihadapi oleh para da'i ialah adanya isu pelanggaran HAM baik yang dilakukan umat Islam ataupun yang diterima oleh umat Islam. Isu pelangaran HAM terjadi pada umat Islam ataupun ditudukan kepada Negara Islam. Di samping itu gangguan yang sering terkecoh umat Islam adalah adanya komunitas ISIS yang berpengaruh baik di Timur Tengah maupun di Indonesia. ISIS sebelumnya adalah lahir akibat dari ekspansinya Amerika Serikat ke Irak tahun 2003. Isu radikalisme dan ekstremisme menjadi kendala bagi da'i dalam memberi pemahaman baik kepada umat Islam sendiri maupun terhadap umat non Islam. Radikalisme dan ekstremisme tidak identik dengan agama tertentu akan tetapi lebih disebabkan ada sekelompok orang yang anti kemapanan dan disebabkan karena keterbelakangan ekonomi dan pendidikan.

Kebangkitan ekonomi dan politik Tiongkok mempunyai efek penting terhadap perkembangan Islam saat ini dan masa datang. Fenomena hubungan Diplomasi dan komunikasi antarbudaya antara Islam-Tiongkok menjadi referensi bagi da'i dalam mengembangkan Islam di dunia global saat ini. Fenomena tersebut karena ekonomi dan politik dunia lebih banyak dipengaruhi oleh Tiongkok. Harmonisasi Islam-Tiongkok sebagai simbol mimpi Islam berkembang seperti abad pertengahan. Namun demikian peran da'i dalam menjalankan Islam yang universal dan menjunjung tinggi nilai-nilai perdamaian serta menjadi harapan bagi dai' dalam menggapai masa depan Islam gemilang. 


\section{Referensi}

Amalia, Y. 2019. Wamenag Minta Semua Masyarakat Tolak Radikalisme.

Www.Liputan6.Com. https://www.liputan6.com/news/read/4101826/wamenagminta-semua-masyarakat-tolak-radikalisme

Erdianto, K. 2019. Dari 15 Kasus Pelanggaran HAM Berat, Hanya 3 Perkara yang Tuntas. Kompas.Com. https://nasional.kompas.com/read/2019/11/07/14015421/dari-15kasus-pelanggaran-ham-berat-hanya-3-perkara-yang-tuntas

Halim, D. 2019. Kapolda Papua Sebut Masih Ada Hoaks Pasca-Kerusuhan Wamena. Kompas.Com. https://nasional.kompas.com/read/2019/11/05/21192451/kapoldapapua-sebut-masih-ada-hoaks-pasca-kerusuhan-wamena

Nainggolan, P. P. 2017. Ancaman ISIS di Indonesia. Yayasan Pustaka Obor Indonesia.

Ravishop. 2014. Cikal Bakal ISIS, Antara Rezim Saddam dan Amerika Serikat.

Www.Sayangi.Com. https://www.sayangi.com/2014/12/13/28917/news/cikalbakal-isis-antara-rezim-saddam-dan-amerika-serikat

Sebayang, R. 2019. Apa Itu OBOR, J alur Sutra Modern China yang J adi Polemik RI? Www.Cnbcindonesia.Com.

https://www.cnbcindonesia.com/news/20190513181838-4-72178/apa-itu-oborjalur-sutra-modern-china-yang-jadi-polemik-ri

Shihab, M. Q. 2007. Tafsir Al-Mishbah, Pesan, Kesan dan Keserasian Al-Qur'an (Volume 11). Lentera Hati.

Syari'ati, A. 1988. Pembangunan Masa Depan Islam. Bandung: Mizan.

Tianyong, Z. 2019. Mimpi dan Jalan Tiongkok Menuju Kejayaan. Jakarta: Yayasan Pustakan Obor Indonesia.

Zahid. 2019. AS Serukan Negara Muslim Kompak Kecam Cina Soal Xinjiang, J okowi Berani? M.Eramuslim.Com. https://m.eramuslim.com/berita/nasional/as-serukannegara-muslim-kompak-kecam-cina-soal-xinjiang-jokowi-berani.htm/2 